\title{
The art of craft in the interior
}

\author{
Lyailya Kuleeva*1[0000-0003-3107-7767], Tatyana Burova ${ }^{1[0000-0001-8965-7225]}$, Ludmila Listovskaya ${ }^{1[0000-0002-5978-1599]}$, \\ IlseyarSaifullina ${ }^{10000-0001-8590-2512]}$, and Ainaz Ibragimova ${ }^{1[0000-0002-2786-5309]}$
}

${ }^{1}$ Kazan State University of Architecture and Engineering, 420043 Kazan, Russia

\begin{abstract}
In relation to the most characteristic architectural styles and movements, this paper discusses the issues of creation and development of artistic crafts that influence the formation and decoration of interior space. The evolution of crafts from a purely utilitarian activity to a form of decorative and applied art used to transform the interior environment by holistic and functional means is being considered through the lens of subjectspatial and functional-artistic organization.
\end{abstract}

Keywords. Art, interior, craft.

\section{Introduction}

At the various stages of societal development, the interior not only served as a special expression to reflect the language of the architects and builders, but also as a canvas for the talent of various artisans such as potter-ceramists, glassblowers, metalworkers, carpenters, and weavers. Weaving reached the highest levels of artistic professionalism along with such arts as painting and sculpture $[1,2]$. The practice grew gradually in correlation with the emergence of more refined and specialied tools and artisans such as Gobelin, Jacquard, Wedgwood and many others have given their names to various products - carpets, fabrics, ceramics and the like, turning the ordinary into artistic [3].

The aim of this article is to show, using some of the most characteristic historical examples, that various crafts such as stonemasonry, carpentry, pottery, stained glass making, weaving, etc. played a significant role in forming interiors for various functional purposes: religious, public and residential, along with purely decorative aspects that arise and develop in the historical and artistic sequence [4].

The order and type of the selected examples presented in this article are not indicative of importance, but rather demonstrate the role of mastery in their consecutive artistic environments [5].

\section{Materials and methods}

\subsection{Research methods}

The tasks set in the article defined a methodical apparatus based on the most progressive methods of conducting research. Among the methods identified are:

*Corresponding author:la_mur@rambler.ru 
- chronological and technological systematisation of crafts that have found their application in interior decoration;

- highlighting the main stages for the formation of artistic crafts;

- analysis of the most characteristic techniques and methods of artistic interior decoration, taking into account the formation and evolution of the crafts themselves;

- identification of the factors that determined the formation of stylistic features in functionally diverse interiors;

- justification of the main stages of crafts' influence on the formation of technology for interior decoration.

\section{Results and discussion}

It can be argued that weaving has been among the earliest forms of craft used for interior decorating. Beginning with simple stripes and cells, then developing into more complex patterns, weaving has been used to create a range of craft items, wicker products, woollen blankets, and carpets, to name a few $[6,7]$. The creation of fabrics from multi-coloured, natural fibres prompted people to develop patterns through interweaving-coloured threads.

Some of the earliest examples of weaving have come from ancient Egypt. A linen shroud made using the rep-weave technique with scarabs and lotus patterns was found in the tomb of Thutmose IV (1400 BC). Tapestry weaving is also to be found in ancient Greece, where Athena was considered to be the patroness of weaving. In Peru, the earliest examples of tapestry weaving were made of wool and cotton, dating back to $2500 \mathrm{BC}$ [8].

The Middle Ages brought the decoration of the walls with woven canvases - trellised on the cold interiors of castles and temples. The earliest European tapestry of the Middle Ages, from the church of St. Gereon in Cologne, was made by Rhine weavers in the 11th century. Some of its motives are images of fantastic animals and plants. Monumentality, flat image, bright yet limited colours are characteristic of the tapestries of this era, often commissioned by churches $[9,10]$. The backgrounds were smooth, and the images were simple geometric patterns and heraldic images. During this time in northern Europe, tapestries were not only used for the decoration of cathedral walls, castles and palaces, but also kept these buildings warm and protected them from drafts.

The tradition of creating tapestries from the paintings of great artists started in Flanders in the fifteenth century [11]. Local weavers had a modest palette of only six colours from which to work, but were able to achieve striking pictorial effects using etching techniques and a special weaving technique known as hatching.

Over time, woven items were used more and more diversely in various interior functions: in the upholstery and decoration of furniture, in the decoration of walls, as well as doors and windows, and in the form of carpets on the walls and floors [12].

In the 16th and 17th centuries, huge sums of money were spent on furnishing interiors with fabrics and fringes. Walls were being adorned with luxurious silk and velvet panels with embroidery or fringed edges, and beds and chairs were being upholstered in rich fabrics [13].

Fabrics for furniture upholstery formed complete ornamental compositions, taking into account the overall dimensions of the furniture as well as the furniture pillows, as each of them was considered to be an independent element of the textile composition [14]. The grand beds of Versailles decorated with rich flowing bedspreads (1672) were designed by Jean Bérain. The bed, made especially for the wedding day of Jacob II (fig.1), was made of simple geometric shapes, decorated with very expensive fabrics, and draped with a decorative canopy [15]. 


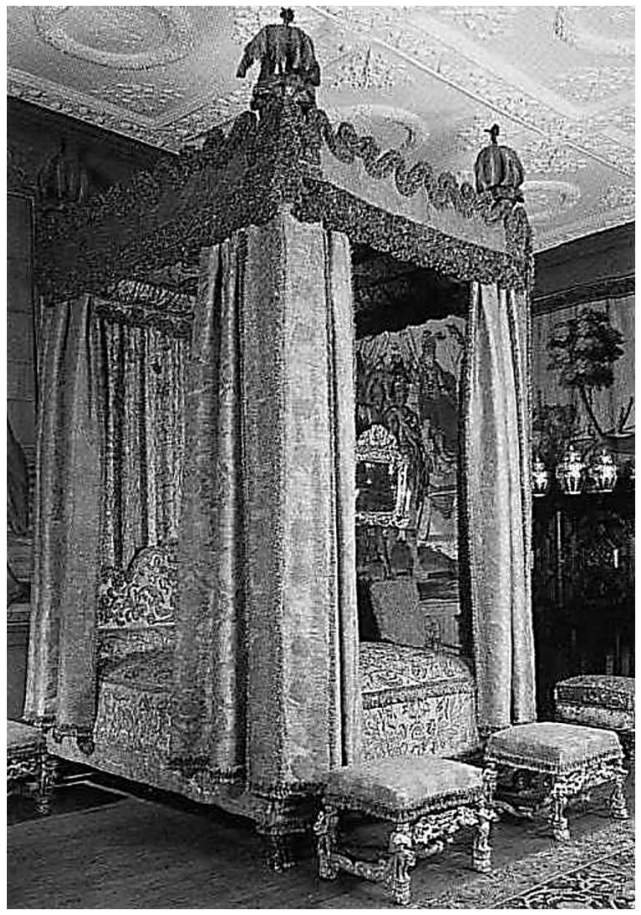

Fig. 1. Bed made especially for the wedding day of Jacob II [15].

Interestingly, the interior of the palace carriage of Karl XI of Sweden was also decorated using fabrics richly embroidered by a royal upholster.

From these examples, it can be easily seen that woven products played a significant role in the formation of interiors throughout a range of architectural instances.

No less significant than weaving, is carpentry, in crafting artistic and decorative interiors through means such as intarsia, inlay, and marquetry [16, 17]. These methods are predominately used for the decoration of furniture and interior surfaces.

In the tomb of Tutankhamun (about 1300 BC), chairs, beds, and other everyday objects were found. Even with minimal use of décor, these objects are examples of exquisite style and form, being an excellent representation of the carpentry of the time [18].

During the late Middle Ages in Europe, the Gothic style of architecture began to demonstrate an extensive use of carpentry for decoration by very skilled artisans. Their skills and the quality of their craft can be seen to have improved significantly over earlier times, as seen by the use of carved wood-panel walls that decorated residential premises. This type of decoration was typical for regions rich in timber $[19,20]$.

The carved wood-panels were complemented with furniture. Wooden benches were widely used in early Gothic cathedrals in France. Wooden thrones and chairs with solid frames were inlaid with openwork carvings [21].

By the middle of the 16th century, carpentry reached its highest level of development in the areas of Germany, Austria, and Switzerland (fig. 2). The most characteristic carving techniques of these regions were «linen folds» imitating the folds of actual fabric, and varieties of floral ornamentation.

Later, during the Renaissance, Baroque and Empire periods, carpentry was widely used in furniture making for various functional purposes in combination with such types of woodworking as intarsia and marquetry. Thereby, carpenters' skills reached such a high level that the silver furniture made for the famous Hall of Mirrors in Versailles Palace, made according to Jean Bérain's sketches, was replaced by wooden furniture decorated with gilding. 


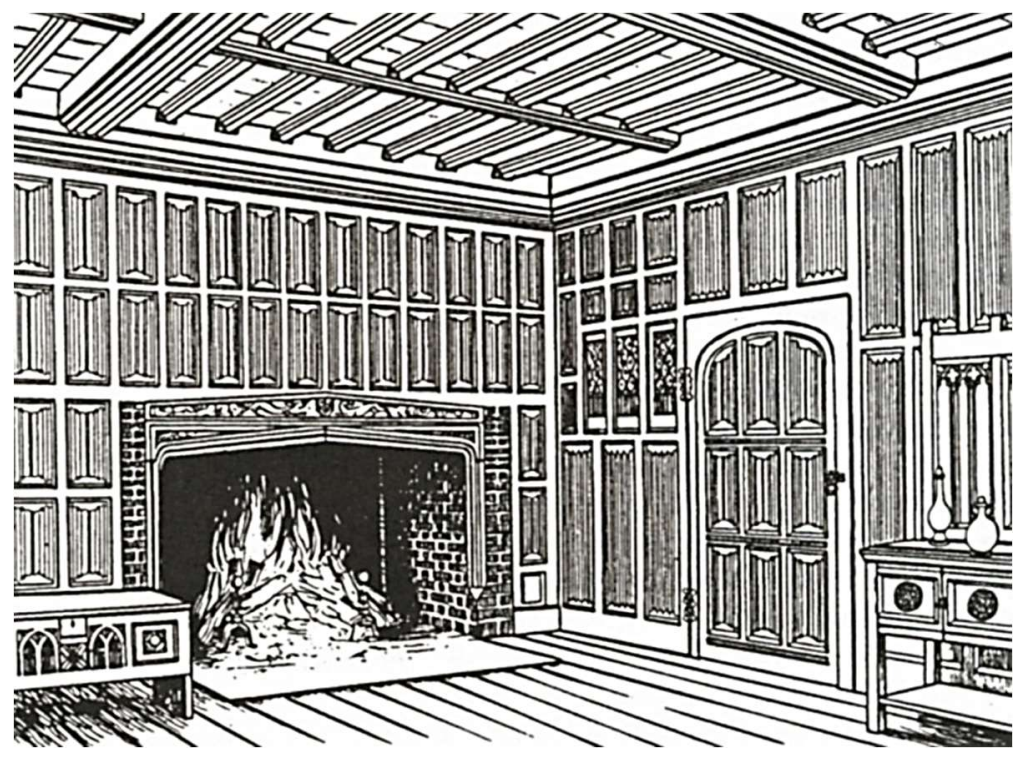

Fig. 2. Living room from the time of Henry VI, early $16^{\text {th }}$ century [21].

Despite the limited variety of furniture, wooden furniture was attractive due to its craftsmanship. Wooden chairs, tables, and dressers were finished with varnish, gilding, or supplemented with inlay [22]. The number of professional methods for achieving these vivid decorative effects increased. Oak and walnut were used most often, while pine and beech were used in special cases with gilded or decorative elements.

The Rococo style, known for pompous and excessive décor, in architecture, as well as interior design, developed the carpentry craft into an independent decorative art. The chairs were designed and assembled by carpenters [23]. Decorations were carved by specialists who either had qualifications in sculpture or those who had woodcarving skills.

The importance of master carpenters' skills became apparent in the forms of the Biedermeier furniture, in the relatively short period of its existence, which demonstrates the beauty of both framework and decoration at the same time [24]. The characteristic features of this style of furniture are laconicism and elegance of form. Dainty forms and beautiful materials, as well as excellent craftsmanship, are the main dignities of the Biedermeier style. The various pieces of furniture created by Michael Thonet are examples of this. The No. 14 chair known as the «Viennese chair» in the history of furniture is still the benchmark of this style $[25,26]$.

Any type of craft leaves vivid examples of craftsmanship in history, developing and transforming over time. A great example of this can be seen through stonemasonry, apparent in many different interior styles of ethnic cultures.

The interiors of the Capilla de Villaviciosa in Córdoba (785, Spain) and the Alhambra Palace in Granada (1354-1391, Spain) built in the late Gothic period, are striking examples of stonemasons' exquisite craftsmanship [27]. The delicate openwork patterns of various arches can hardly be perceived as made of stone. Columns supported arches of red and white stone in the immense hall of the Great Mosque of Córdoba. The columns' capitals were decorated with abstract carvings. Artistic carvings of the capitals and striped arches were the only decorative elements of the interior.

The art of stonemasonry has played an important role in the formation and development of French and English Gothic interiors. Gothic Architecture was characterised by different techniques that transformed over the course of its development. Each of the periods of Gothic 
style development, either Early Gothic (1140-1250), High Gothic (1194-1400) or Late Gothic (1350-1550) have striking interior solutions for cathedrals and churches [28].

Gothic interiors are mainly comprised of three parallel structural spaces of naves, columns and a lancet arch resting above, but they represent countless design solutions and types of artistic expression, turning them into the main artistic interior decoration by virtue of the stonemasons' mastery [29]. The trunks of the columns consist of several separate verticals and the lancet arches' nervures interweaving to create the impression of graceful rapports, built according to ornamental arrangement principle, while also performing a constructive role. The interiors of Notre-Dame d'Amiens Cathedral (1220-1288, Amiens, France), SaintMaclou Church (1463-1520, Rouen, France), as well as the Chartres, Beauvais and Bourges Cathedrals are representative of this High Gothic period [30].

The Chapel of Henry VII in Westminster Abbey (London, 1503-1519) is considered to be the most exquisite example of the Gothic style in England. The stone nervures of the chapel were embellished with decorative tracery that made the stone look like the thinnest and finest lace. The interior of King's College Chapel at Cambridge (1446-1515, London) is another fine example of Gothic architecture [31]. The fan vaulting and walls filled with soaring stained-glass windows made stone structures look weightless.

While speaking of the Gothic style, it is impossible not to mention the skill of stainedglass artisans. The aforementioned Notre-Dame de Chartres Cathedral is decorated with an exquisite composition of stained-glass windows, consisting of a large central rose window with a diameter of $12 \mathrm{~m}$ and five lancet windows below it [32].

The emergence of technology for producing sheet glass with the addition of various pigments made it possible not only to illuminate the interiors of cathedrals more fully, but also to give the interiors unexpected colour solutions. Therefore, the walls on the second level of the royal chapel of Sainte-Chapelle (1242-1248, Paris) were replaced with slender pillars which made it possible to fill all the freed-up space with stained glass windows. As a result, the interior makes an impression of the space filled with multiple colours.

Interior glass became popular during the Baroque and Rococo periods and on [33]. The unusual use of mirrored glass emphasises the splendour of the Palazzo Colonna Gallery in Rome (fig.3) where the mirrored surfaces were painted with elegant floral ornaments, as if to continue the paintings on the ceiling.

The emergence of a wide variety of engraving and glass carving contributed to the use of glass as a leading material for all kinds of lamp manufacturing [34]. During the Neoclassical period, lead glass production began to increase as a material for lamps. Lead glass was actively used in the manufacturing of candelabra, having a greater ability to refract and diffuse light as well as better reflecting either sun or flame [35]. In this case, not only the colourless, but also the coloured glass was used, most often cobalt.

The craft of forging and casting can seem, at first glance, to be quite removed from the sphere of interior decoration. However, luxurious cast silver frames, framing mirrors, pieces of furniture, lamps and interior accessories are produced by masters in forging and casting for Baroque and Rococo interiors [36].

A special place is occupied by products made using the Kasli casting technology. Kasli casting is a branch of the Russian art industry for casting iron products. A special composition of iron is being used for castling as it is viscous and allows for subtle and complex castings with accuracy and quality surface finish.

Artistic casting originated in the Urals in the village of Kasli, in the first half of the 19th century at the copper smelter founded by Nikita Demidov in the middle of the 18th century, where a wide variety of products were produced before the revolution: all kinds of household items, for example, cauldrons, bowls, decorative dishes, vases with relief and openwork ornaments, table sculptures, and architectural details. 
The Kasli cast-iron pavilion made for The Exposition Universelle held in Paris in 1900 occupies a special place among the products made at the Kasli plant. The pavilion, designed by the architect Eugene Baumgarten was an openwork cast-iron room, where about 1.5 thousand of the best samples of 'cabinet' items of Kasli casting were exhibited: sculpture, candlesticks, openwork vases and plates, boxes, writing instruments. These products were awarded a gold medal and the Grand Prix of the exhibition.

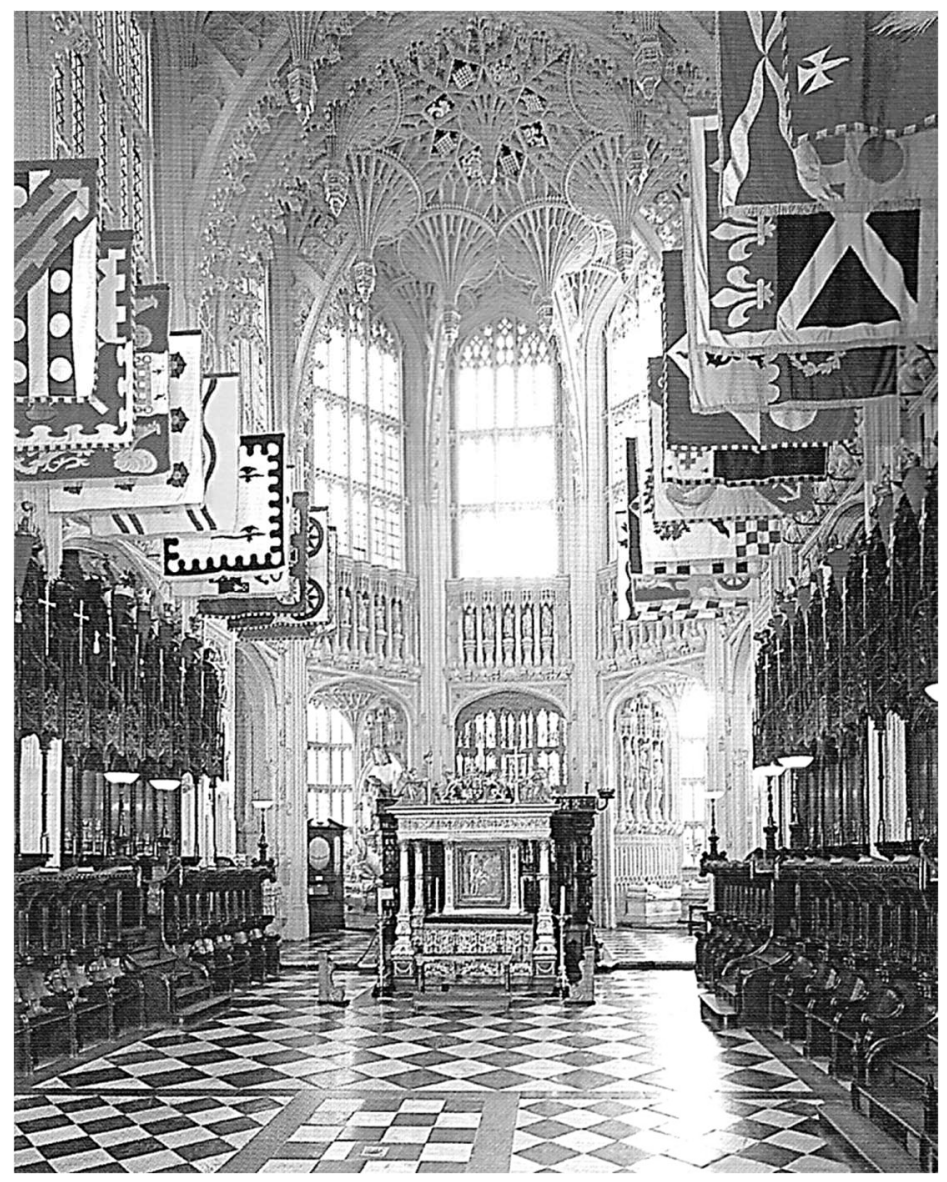

Fig. 3. Henry VII Chapel (Westminster Abbey, London, 1503-1519) [33].

In London, at the Shropshire metal factory, they began to cast iron furniture using foliage patterns inspired by Gothic forms, based on Dresser's sketches from the mid-19 ${ }^{\text {th }}$ century.

Perhaps, pottery could be attributed to being one of the most ancient and most diverse crafts in its application to interior spaces [37]. These include ceramic tiles for floors and walls, ceramics such as wall dishes from the Renaissance, vases and porcelain miniatures, mosaic panels and even interiors completely made using the mosaic technique (Ravenna Mosaics heritage, 400-500 AD), special ceramic tiles intended for facing stoves, unique products made of porcelain and faience, including unique porcelain iconostases in Orthodox churches.

\section{Conclusion}

Pottery products have an ancient history that is still legitimate and relevant in modern interiors, thanks to the latest production technologies, from miniatures to large panels. 
The examples of interior formation considered in this article are intended to demonstrate the role and importance of particular types of crafts in the process of creating a subject-artistic environment, taking into account the historical aspect of the art and development throughout architectural styles.

Each of the considered examples, however limited, are, in the authors' opinion, representative and convincing examples revealing the main thesis of this article, that speak to the role and significance of applied crafts in interior design

\section{References}

1. B.A. Vvedensky. Bolshaya Sovetckaya Encyclopedia, second edition 13, 610 (1952).

2. A. Aronov. Art of Westaern Europe (architecture abroad XIX-XX centuries), 413 (2003).

3. N. Riley. Elements of design. Development of design and style elements from the Renaissance to Postmodernism, 546 (2004).

4. C. Kèlouèj. Style elements. Encyclopedia of architectural details, 592 (2006).

5. J.F. Pyle.Interior Design. 6000 years of history, 612 (2018).

6. S. Adams.Guide to style «Arts and Crafts Movement», 128 (2000).

7. S. Mikhailov, A. Mikhailova, N. Nadyrshine. Multilinear approach to representing the historical evolution of urban design (industrial and post-industrial periods, IOP Conference Series: Materials Science and Engineering 890, (012006) (2020). DOI: 10.1088/1757-899X/890/1/012006.

8. R. Cooper. Design research - Its 50-year transformation, Design Studies 65, 6-17 (2019). DOI: 10.1016/j.destud.2019.10.002.

9. K. Dorst. Co-evolution and emergence in design, Design Studies 65, 60-77 (2019). DOI: 10.1016/j.destud.2019.10.005.

10. John S. Gero. Nascent directions for design creativity research, International Journal of Design Creativity and Innovation 8 (3), 144-146 (2020). DOI: 10.1080/21650349. 2020.1767885.

11. B. van Berkel. Architecture and the Impact of the Fourth Industrial Revolution, Architectural design 90 (5), 126-133 (2020). DOI: 10.1002/ad.2619.

12. M. Taylor. Time Matters: Transition and Transformation in Architecture. Architectural design, Special Issue: Architecture Timed: Designing with Time in Mind 86 (1), 42-49 (2016). DOI: 10.1002/ad.2000.

13. M. Bressani. The Performative Character of Style. Architectural Histories 6 (1), 15 (2018). DOI: 10.5334/ah.322.

14. M. Quinn, Design, History \& Time, Journal of Design History 33 (2), 189-191 (2020). DOI: $10.1093 / \mathrm{jdh} / \mathrm{epaa} 002$.

15. L. Skipper. The Evolution of Wallpaper Interior Design Schemes in a Commercial Setting: The Interiors of the St Pancras Renaissance Hotel (Midland Grand Hotel), London 1870-1980s, Journal of Design History 30 (3), 315-334 (2017). DOI: 10.1093/jdh/epw039.

16. T. Otto. History in and For Design, Journal of Design History 29 (1), 58-70 (2016). DOI: 10.1093/jdh/epv044.

17. A. Popp, R. Holt, Josiah Wedgwood, Manufacturing and Craft, Journal of Design History 29 (2), 99-119 (2016). DOI: 10.1093/jdh/epv048.

18. M. Amah Edoh, Redrawing Power? Dutch Wax Cloth and the Politics of «Good Design», Journal of Design History 29 (3), 258-272 (2016). DOI: 10.1093/jdh/epw011.

19. S. Ruecker, J. Roberts-Smith. Design Research: Objects, Procedures, and New Understanding, Technology, Architecture + Design 2 (1), 11-14 (2018). DOI: 10.1080/24751448.2018.1420959. 
20. A. Kuzminikh, S. Korotkova. Adaptation of the shoreline of urban development to special environment conditions, IOP Conference Series: Materials Science and Engineering 890 (1), 012019 (2020). DOI: 10.1088/1757-899X/890/1/012019.

21. A. Galimullina, S. Korotkova. Adapting the architecture of school buildings in the context of humanizing the environment, IOP Conference Series: Materials Science and Engineering 890 (1), 012008 (2020). DOI: 10.1088/1757-899X/890/1/012008.

22. B.T. Christensen, L.J. Ball. Dimensions of creative evaluation: Distinct design and reasoning strategies for aesthetic, functional and originality judgments, Design Studies 45 (A), 116-136 (2016). DOI: 10.1016/j.destud.2015.12.005.

23. N. Crilly, R. Moroşanu Firth, Creativity and fixation in the real world: Three case studies of invention, design and innovation, Design Studies64, 169-212 (2019). DOI: 10.1016/j.destud.2019.07.003.

24. H. Casakin, G.V. Georgiev. Design creativity and the semantic analysis of conversations in the design studio, International Journal of Design Creativity and Innovation 9 (1), 61-77 (2021). DOI: 10.1080/21650349.2020.1838331.

25. L.D. Busbea. Soft Control Material: Environment and Design c.1970, Journal of Design History 30 (2), 139-156 (2017). DOI: 10.1080/21650349.2016.1246205.

26. J.A. Stein. Hidden Between Craft and Industry: Engineering Patternmakers' Design Knowledge, Journal of Design History 32(3), 280-303 (2019). DOI: 10.1093/jdh/epz012.

27. M. Quinn, Design, History \& Time, Journal of Design History 33 (2), 189-191 (2020). DOI: $10.1093 /$ jdh/epaa002.

28. P. Garvey, A. Drazin.Design Dispersed: Design History, Design Practice and Anthropology, Journal of Design History 29 (1), 1-7 (2016). DOI: 10.1093/jdh/epv054.

29. A. Popp, R. Holt. Josiah Wedgwood, Manufacturing and Craft, Journal of Design History 29 (1), 99-119 (2016). DOI: 10.1093/jdh/epv048.

30. C.M.E. Guth. Crafting Community: George Nakashima and Modern Design in India, Journal of Design History 29 (1), 366-384 (2016). DOI: 10.1093/jdh/epw015.

31. S. Mikhailov, R. Khafizov, A. Mikhailova, N. Nadyrshine, L. Nadyrshine. Supergraphics as a project and artistic method in design of a modern city, IOP Conference Series: Materials Science and Engineering 890, (012003) (2020). DOI:10.1088/1757899X/890/1/012003.

32. A.N. Novikova. Experience of optimization of design process in an example of a real object in Kazan, Izvestiya KGASU 4 (18), 100-106 (2011).

33. A.F. Ibragimova, A.S. Mikhaylova. Conceptualism in the modern architectural environment (an example of city sculpture), Izvestiya KGASU 3 (37), 34-40 (2016).

34. I.Z. Saifullina. On the history of interior decoration, Izvestiya KGASU 4 (18), 51-57 (2011).

35. V.A. Elyukhina, I.V. Krasnobaev. On the question of relationship of architecture and building technologies (upn the materials of foreign publications), Izvestiya KGASU 2 (48), 40-47 (2019).

36. A.R. Lotfullina, I.V. Krasnobaev. On the question of the mutual influence of architectural design and stage design, Izvestiya KGASU 3 (49),18-26 (2019).

37. D.A. Nadyrova. Profitable houses of Kazan of the end of XIX-beginning XX centuries, as a multi-functional complex, Izvestiya KGASU 2 (36), 57-63 (2016). 